\title{
Comparing nursery behavior, field plant yield and fruit quality of in vitro and in vivo propagated strawberry mother plants
}

\author{
Franco Capocasa ${ }^{1}\left[\right.$ [ . Francesca Balducci ${ }^{1} \cdot$ Micol Marcellini $^{1} \cdot$ Danilo Bernardini $^{2} \cdot$ Oriano Navacchi $^{3}$. \\ Bruno Mezzetti ${ }^{1}$
}

Received: 3 July 2018 / Accepted: 9 September 2018 / Published online: 14 September 2018

(c) The Author(s) 2018

\begin{abstract}
In different countries, mostly in EU, rules for strawberry nursery propagation impose the use of micropropagation only to produce stock virus free plant followed by at least three nursery production cycles in the field before selling these plants to growers. This limit has been imposed by problems concerning true-to-type plants observed in micro-propagated plants of some cultivars, with higher genotypic and phenotypic instability, and the incorrect use of higher concentrations of cytokinin in the proliferation phase. This production system of certified plants has high economic and environmental costs without a final guarantee on the sanitary state of the plants. New knowledges on in vitro techniques and new cultivars with higher genetic stability can offer the opportunity to improve the use of micropropagation in strawberry nursery industry. With the aim to propose a new protocol for strawberry propagation, an experimental trial was set up to compare the behavior of frigo and micro-mother plants of cv. Alba, a well know commercial cultivar in EU, in two cycles of nursery runner production and the yield, to verify in two successive cycles the fruit quality of daughter plants grown in open field conditions. The results confirmed the equivalence of the two types of mother plants both in plant nursery production and subsequently in field fruit production. Therefore, the direct use of micro-mother plants for nursery productions of frigo-plants for growers offer an alternative option for large scale frigo-plant nursery production.
\end{abstract}

Keywords Fruit quality $\cdot$ Mother plants $\cdot$ Micropropagation $\cdot$ Nursery $\cdot$ Yield

$\begin{array}{ll}\text { Abbreviations } \\ \text { ACY } & \text { Total anthocyanin content } \\ \text { BA } & \text { Benzil adenine } \\ \text { C* }^{*} & \text { Chroma } \\ \text { L*}^{*} & \text { Lightness } \\ \text { MS } & \text { Murashige and Skoog basal medium } \\ \text { SSC } & \text { Soluble solids concentration } \\ \text { TA } & \text { Titratable acidity } \\ \text { TAC } & \text { Total antioxidant capacity } \\ \text { TPH } & \text { Total polyphenols content }\end{array}$

Communicated by Sergei Krasnyanski.

Franco Capocasa

f.capocasa@univpm.it

1 Department of Agricultural, Food and Environmental Sciences (D3A), Università Politecnica delle Marche, Ancona, Italy

2 Raggi Vivai, Strawberry Nursery, Cesena, FC, Italy

3 Vitroplant Italia Srl, Cesena, FC, Italy

\section{Introduction}

The continuous growth of strawberry demand on international markets through all periods of the year, has necessitated high level of innovation in the production chain of this important horticultural fruit crop. Many innovations have been introduced for increasing adaptation to different pedoclimatic conditions and new cultivation systems for open field, tunnel and greenhouse productions, including soil-less cultivations. These changes are accompanied by a continuous increase in requests for high quality healthy plants for the cultivation systems adopted in the different growing areas (Mezzetti et al. 2018).

Massive production of strawberry plants in vitro goes back to the 1970s where it was introduced in 1974 (Boxus 1974; Boxus et al. 1977) offering an interesting improvement to this very strict and slow scheme. Therefore, within few years, European growers had adopted micropropagation that resulted in a simpler technical process able to produce large amounts of healthy plants. In fact, after a first industrial application in Germany (Westphalen and Billen 1976), in 
about 10 years the annual production of micropropagated strawberry plants reached 7.5 million. This high-quality material, used as stock mother plants, produced a large part of the billion conventional strawberry plants produced annually in the world (Boxus 1992).

To this massive production, were associated different field trials meant to compare yield and fruit quality of micropropagated plants in comparison with in vivo produced frigo-plants, which initially did not give any statistical differences (Damiano 1980; Boxus 1985; Navatel et al. 1986). Conversely, in other trials in different production conditions, some sporadic occurrences of abnormal fruit setting mainly related to a new hyper-flowering habit that entailed malformations and reduced fruit size were observed (Sansavini and Gherardi 1980; Swartz et al. 1981). These negative variations were observed sporadically, only for specific cultivars and mainly when using plants produced in vitro after a long-term proliferation phase. These alterations, even if sporadic, had a high impact on the strawberry nursery production (Navatel et al. 1986). Instead of solving the problem with a scientific approach aimed at finding solutions for preventing these variations, different countries used these results to set up new legislations with specific limitations or even a full rejection of micropropagation in strawberry nursery production.

At that time, commercial laboratories driven with the need of fast mass production of new cultivars and with the lack of knowledge on the determinants of phenotypic and 'somaclonal variation', described by Larkin and Scowcroft (1981), made the mistake of not taking into account the following three major factors: (a) the importance of reducing cytokinin concentration in the proliferation medium, at that time $1 \mathrm{mg} / \mathrm{l}$ of BA was the minimum concentration used (Keiko et al. 2003; Anderson et al. 1982); (b) the importance to not exceed the number of subcultures during proliferation stage (Jemmali et al. 1995a, b) the response of genotypes/ cultivars to these micropropagation conditions.

Pheno-morphological characterization still represents the main step for the identification of genetic stability of micropropagated strawberry plants (da Fonseca et al. 2013). Deeper characterization of clonal stability can be achieved with the application of DNA-based markers (Debnath 2017).

Micropropagation protocol not taking into consideration these three main factors frequently produced plants with variations in leaf area, leaflet size, hairiness of leaf stalks and runners number (Karhu 2001; Borkowska 2001), mostly noticeable in the 1st and 2nd vegetative generation (V1 and V2) (Sansavini et al. 1991). Some reports noted higher fruiting linked to enhanced shoot proliferation and flower bud differentiation (Jemmali et al. 1995a) but associated with marked fruit quality decline (Lopez-Aranda et al. 1994; Boxus et al. 2000). Moreover, micropropagated plants, in some case, produced higher number of runners through the enhanced axillary bud activity stimulated by the addition of a very high amount of BA into the proliferation medium. Most variations exhibited in micropropagated strawberry plants were defined as epigenetic, because the variation characteristics disappeared after 2 or 3 years (Szczygiel et al. 2002; Litwinczuk 2004).

It is for the risk of these variations that, still nowadays, micropropagation is not used for strawberry nursery propagation industry but only for meristem culture, after heat therapy, to produce and maintain virus-free nuclear stock plants (stock 0). In fact, for the legislation of many countries, including Italy (Lucchi et al. 2004), in vitro culture can only be used for the production of few safe elite plants, and not in the other successive phases of nursery production. Furthermore, it is mandatory that at least three, sometime four generations of in vivo on filed nursery propagation, must follow the micropropagation phase before the distribution of certified plants to the farmers (Sansavini et al. 1991).

More recent studies developed new protocols for strawberry in vitro propagation, including also the use of bioreactors (Debnath 2009), demonstrating that tissue culture remains a powerful tool for strawberry propagation with reduced gene methylation and epigenetic variability (Chang et al. 2009).

The new knowledges are supporting the renewed interest of including micropropagated plants in strawberry nursery production. This demand is motivated by the following reasons:

- The four in vivo propagation cycles, expected by the legislation after in vitro production of stock plants, are increasing the incidence of pathogens new infection before reaching the farmers hence, reducing the sanitary state of the plants.

- The need of speeding up the initial larger production of new cultivars to meet the high demand on the market.

- The strawberry nursery market is now changing for the increasing request of fresh plants, instead of frigo plants (Lisiecka 2009), to be used in programmed out of season production.

Clearly, micropropagation cannot completely replace the standard nursery production methods. However, the development of new protocols specifically adapted to each new cultivar, able to guarantee clonal fidelity and cost efficiency of micropropagated plants, can increase the role of the in vitro culture in strawberry nursery industry, to produce healthy mother plants for in vivo nursery production of cold stored and fresh plants.

The aim of this study is to demonstrate the efficiency of a propagation protocol based on the use of micropropagated plants as mother plants for the in vivo production of frigo strawberry plants. With this aim, in vitro plants of cv. Alba, 
proliferated in low cytokinin proliferation medium and for a limited number of subcultures, were compared with standard frigo plants, as source of mother plants for the in vivo production of massive numbers of frigo plants. The two sources of mother plants showed the same nursery propagation capacity of high quality plants. The clonal fidelity and yield of plants with the two origins were confirmed by measuring quantitative and qualitative fruit production from open field cultivation of the daughter plants. Data reported include two nursery production cycles and the successive two cycles of open field cultivation of the daughter plants.

\section{Materials and methods}

\section{Mother plant in vitro and in vivo propagation}

In vitro plants of strawberry $\mathrm{cv}$. Alba were produced by the commercial laboratory (Vitroplant Italia Srl) by starting from apical shoots of active runners collected from virus free mother plant grown in screen-house. They were surface disinfected for $15 \mathrm{~min}$ in a water solution with $1 \%$ (vol/ vol) active chloride, prepared with a Sodium hypochlorite $(\mathrm{NaOCl})$ commercial product, and successively washed three times with sterile water. Disinfected shoots were placed in tubes with MS medium (Murashige and Skoog 1962) added with $0.35 \mathrm{mg} / \mathrm{l}$ of BA, $30 \mathrm{~g} / \mathrm{l}$ of sucrose and $6 \mathrm{~g} / \mathrm{l}$ commercial agar (all chemicals were supplied by Duchefa Biochemie). Developed shoots were transferred in glass jars (Bormioli $500 \mathrm{G}$ ) containing the same MS medium for starting the proliferation phase. Proliferating shoots were sub-cultured every 3 weeks for a maximum eight subcultures. The elongation and rooting of the shoots was obtained by the use of the same culture medium used for proliferation, without cytokinin addition. After 4 weeks, the shoots were transplanted on a substrate composed of peat (80\%) and perlite (20\%), in $100 \mathrm{~mL}$ pots, and transferred in the green-house for a 40 days-long acclimatization period. The proliferation and acclimatization phases were programmed so as to have well developed plants ready to be planted in the nursery at the same time as the in vivo plants (May). The in vivo propagated mother plant (category A-shoot diameter 8-12 mm) of the same cultivar were obtained the previous year by Pre-multiplication (CP2) mother plants (Lucchi et al. 2004), stored as frigo plants (at $-2{ }^{\circ} \mathrm{C}$ ) until planting time in the commercial nursery, at the same time as the in vitro plants.

\section{Nursery production}

Two nursery production cycles were followed by planting in May (2010 and 2011) and harvesting in January (2011 and 2012) of the mother plants of cv. Alba propagated in vitro and in vivo. The nursery plantings were done at the Raggi
Vivai nursery, located in Ravenna $\left(43^{\circ} 31^{\prime} \mathrm{N} 12^{\circ} 06^{\prime} \mathrm{E}\right)$, in sandy soil with a $\mathrm{pH}$ of about 6.5 , typical for strawberry nursery production. Plants were placed in single rows, $0.5 \mathrm{~m}$ within the row and $1.6 \mathrm{~m}$ between the rows, with a plantation density of 12.500 plant/ha. The two types of plants were distributed in the field using a randomized complete block experimental design with three plots of fifteen plants each, for both types of plants. In vivo nursery plant growth and proliferation was followed by standard treatments of fertilization, weed control and irrigation above foliage (Pertuzé et al. 2006). Plants were let to freely produce runners throughout the vegetative season. Data was collected just before the end of the vegetative season (end of October 2010 first cycle and end October 2011 second cycle), this data included:

- number of shoots per plant;

- number of leaves per plant

- length of leaf petiole ( $\mathrm{mm}$ )

- length and width of middle leaflet (mm)

While, at the harvesting of rooted runners (January 2011 and January 2012) were collect data on the following parameters:

- number of runners per plant;

- number of runners chain per plant;

- number of marketable runners classified by the shoot diameter (Ø $\mathrm{mm})$ as described by Lucchi et al. (2004):

- Class $\mathrm{A}^{++}(\varnothing \geq 15 \mathrm{~mm})$

- Class $\mathrm{A}^{+}(12.0 \leq \emptyset \leq 14.9 \mathrm{~mm})$

- Class A $(8.0 \leq \varnothing \leq 11.9 \mathrm{~mm})$

- Class $\mathrm{A}^{-}(6.0 \leq \varnothing \geq 7.9 \mathrm{~mm})$

- Discarded runners $(\varnothing<5.9 \mathrm{~mm})$

After harvesting, all plants (class A marketable runners) were cold stored $\left(-2{ }^{\circ} \mathrm{C}\right)$ until the planting period in the cultivation field as 'Frigo plants' (Fig. 1).

\section{Plant development, yield and fruit quality}

Strawberry plants of cv. Alba, harvested from the nursery, but originated from frigo and micro-propagated mother plants, were planted at the "P. Rosati" Experimental Farm of the Polytechnic University of Marche, located near Ancona $\left(43^{\circ} 31^{\prime} \mathrm{N} 13^{\circ} 36^{\prime} \mathrm{E} .46 \mathrm{~m}\right.$ altitude). The planting was on nonfumigated soil, having $\mathrm{pH} 7.9$, active calcium $9 \%$ and a texture of $40 \%$ clay, $25 \%$ sand and $35 \%$ silt. The plants were grown in open field conditions using the plastic hill culture production system. Two cultivation cycles and fruit harvests were followed: plants harvested in the nursery in January 2011 were planted in July 2011 and fruits harvested in May 


\section{(A) STANDARD CERTIFICATION PROCEDURE}

In vitro shoot proliferation of meristematic apex from stolons after thermotherapy treatment.

Max 3-4 subcultures of in vitro proliferation on MS basal medium with low BA Concentrations (0.25-

$0.35 \mathrm{mg} / \mathrm{l}$ ) and rooting on MS without PGRs

In vivo acclimatization of mother
plants
for the nursery.

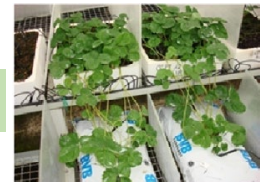

CPP: In vivo propagation of highly controlled stock of mother plants.

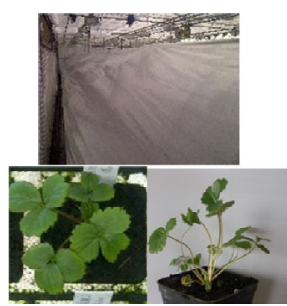

\section{(B) CERTIFIED PLANTS WITH} MICROPROPAGATION

In vitro shoot proliferation of meristematic apex from stolons after thermotherapy treatment.

Max 8-10 subcultures of in vitro proliferation on MS basal medium with low BA Concentrations (0.25-

$0.35 \mathrm{mg} / \mathrm{l}$ ) and rooting on MS without PGRs.

$1^{\circ} \mathrm{Y}$

In vivo acclimatization of mother plants for the nursery.

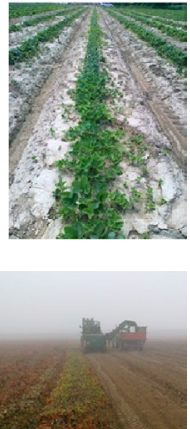
the healthy and true-totype Micro-propagated mother plants.

Nursery harvesting of frigo plant (in December-January).

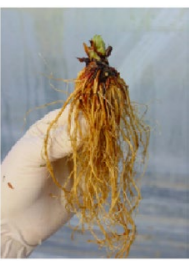

Healthy and true-to-type the market Nursery plant to be sold on

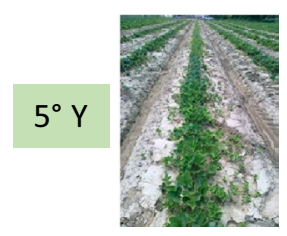

CP2: Open field propagation of controlled (only $0,2 \%$ ) of mother plants.
Nursery plantation (in April) of the mother plants.
Nursery harvesting of frigo

plant (in December-January). $5^{\circ} \mathrm{Y}$

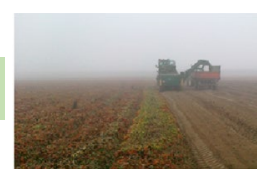

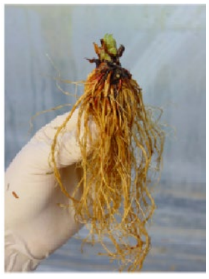

Healthy ?? and true-to-type

Nursery plant to be sold on the market

Fig. 1 Traditional production system (a) and use of micropropagation for mother plant production in the nurseries (b), to obtain certified strawberry plants 
2012; while plants harvested in January 2012 were planted in July 2012 and fruits harvested in May 2013.

For each cultivation cycle, all frigo plants were planted in the last week of July, in four plot-replicates of ten plants, and they were grown in standard cultivation conditions with a plastic film mulched double row $(30 \mathrm{~cm}$ distance between plants, $1.5 \mathrm{~m}$ between rows), on a raised bed, with drip irrigation. Plants were cultivated using a standard integrated pest management system.

During the two fruiting periods (2012 and 2013), data were collected on vegetative and productive traits; shoot numbers per plant, plant height, numbers of leaves per plant, petiole leaf length, width and height of middle leaflet, beginning of flowering (25\% flowers open), floral axis number per plant, floral axis length, precocity index (Capocasa et al. 2016), average fruit weight, total fruit yield per plant (reached after about six to seven harvests), discarded fruit weight per plant (as small $\emptyset<22 \mathrm{~mm}$, rotten and deformed fruit).

Samples of all fruits at the second and third harvest were collected, and used for fruit quality analyses, including: Soluble solids concentration (SSC), determined using a handheld refractometer (ATAGO), and expressed as ${ }^{\circ}$ Brix; Titratable Acidity (TA), determined starting from $10 \mathrm{~mL}$ juice diluted with distilled water $(1: 2, \mathrm{v}: \mathrm{v})$ and titrated with $0.1 \mathrm{~N}$ $\mathrm{NaOH}$ solution to $\mathrm{pH} 8.2$ (results were expressed as meq $\mathrm{NaOH} / 100 \mathrm{~g} \mathrm{FW}$ ); fruit Firmness, measured by a penetrometer 327 (Effegì, Ravenna, Italy) with star probe $6 \mathrm{~mm}$, and expressed as grams; berry skin colour was measured with a chroma meter CR 400 (Konica Minolta, Tokyo, Japan) that reports colour in terms of lightness $\left(\mathrm{L}^{*}\right)$ and Chroma $\left(C^{*}\right)$; $L^{*}$ refers to the lightness of a colour from black $=0$ to white $=100 ; C^{*}$ refers to intensity of a colour whith 0 being achromatic. With the same harvests, fruit samples were frozen and thereafter, a methanolic extraction of the following nutritional parameters: total antioxidant capacity (TAC), total anthocyanin content (ACY), and total polyphenols content (TPH), were analysed, using the analytical methods described by Diamanti et al. (2012a, b).

\section{Statistical analysis}

Data from the two nursery production cycles (runner's production and quality), and from two fruit production cycles (fruit yield and nutritional quality) were analyzed using STATISTICA software (Statsoft Inc., Tulsa, OK, USA). Data were subjected to factorial analysis of variance (ANOVA) for mean comparison, and inter-genotypes significant differences were calculated according to Student Newman Keuls test. Differences at $\mathrm{p}<0.05$ were considered statistically significant. Data presented and discussed are referred to average values of two cycles of runner production in the nursery (2011-2012) and of the fruit harvest form two cultivation cycles (2012 and 2013) of fruit production.

\section{Results}

\section{Plant vegetative growth in the nursery}

The two types of mother plants (frigo and micro-mother plants) grown in the nursery, produced new runners showing significant (ANOVA) differences only for some parameters of vegetative development (shoot numbers, leaf number and petiole leaf length) (Table 1). Strawberry frigo-mother plants had a higher vegetative development only because they produced more shoots and leaves, with a shorter petiole. This difference can be explained by the higher vegetative strength of frigo-mother plant in respect to the micro-mother plants ones, that can affect the initial development after planting in the nursery. Those initial odds could be reduced by a stronger and better development of micro-mother plants after the acclimatization period and before transferring to the nursery.

The two types of plants, independently to the year of cultivation, had the same development of the other vegetative parameters: size of the middle leaflet (middle leaflet width and middle leaflet height) (Table 1).

\section{Runners production and quality in the nursery}

The total production of runners was the main parameter used to test for the efficiency of mother plants for nursery production system (Table 2). The cultivation conditions of the two production cycles influenced the yield and quality of runners produced per plant by frigo and micro-mother plants,
Table 1 Plant vegetative growth in the nursery of frigo and micro-mother plants, cv. Alba, measured at the end of the proliferating period (October 2010 and 2011)

\begin{tabular}{llllll}
\hline Type of plant & Shoot number/plant & Leaves number/plant & $\begin{array}{l}\text { Petiole leaf } \\
\text { length }(\mathrm{mm})\end{array}$ & $\begin{array}{l}\text { Middle leaflet } \\
\text { width }(\mathrm{mm})\end{array}$ & $\begin{array}{l}\text { Middle } \\
\text { leaflet height } \\
(\mathrm{mm})\end{array}$ \\
\hline ALBA_Frigo & $2.5 \pm 0.6 \mathrm{a}$ & $26.7 \pm 6.3 \mathrm{a}$ & $13.6 \pm 3.0 \mathrm{~b}$ & $84.1 \pm 1.1 \mathrm{~ns}$ & $69.5 \pm 1.1 \mathrm{~ns}$ \\
ALBA_Micro & $1.9 \pm 0.7 \mathrm{~b}$ & $20.6 \pm 5.9 \mathrm{~b}$ & $15.3 \pm 4.2 \mathrm{a}$ & $85.3 \pm 1.2 \mathrm{~ns}$ & $67.3 \pm 0.9 \mathrm{~ns}$ \\
\hline
\end{tabular}

Means \pm standard error of the two production cycles. Student Newman Keuls test; $p<0.05$ 
Table 2 Frigo and micro-mother plants, cv. Alba, runners production and quality measured at the two harvests of rooted runners (January 2011 and 2012)

\begin{tabular}{llllllll}
\hline Type of plant & $\begin{array}{l}\text { Marketable runners/ } \\
\text { mother plant (no.) }\end{array}$ & $\begin{array}{l}\text { Runner chain/ } \\
\text { mother plant (no.) }\end{array}$ & \multicolumn{5}{l}{ Quality nursery production—class of plants (\%) } \\
\cline { 5 - 8 } & & $\mathrm{A}^{++}$ & $\mathrm{A}^{+}$ & $\mathrm{A}$ & $\mathrm{A}^{-}$ & Discarded runners \\
\hline ALBA_Frigo & $70.3 \pm 33.8 \mathrm{~ns}$ & $17.5 \pm 6.5 \mathrm{a}$ & $8.6 \pm 5.1 \mathrm{~ns}$ & $14.1 \pm 4.2 \mathrm{~ns}$ & $32.9 \pm 4.7 \mathrm{~ns}$ & $22.6 \pm 2.7 \mathrm{~ns}$ & $21.7 \pm 10.6 \mathrm{~ns}$ \\
ALBA_Micro & $61.2 \pm 27.0 \mathrm{~ns}$ & $14.1 \pm 2.5 \mathrm{~b}$ & $7.8 \pm 4.2 \mathrm{~ns}$ & $12.1 \pm 4.5 \mathrm{~ns}$ & $30.0 \pm 4.0 \mathrm{~ns}$ & $22.6 \pm 2.3 \mathrm{~ns}$ & $27.4 \pm 10.0 \mathrm{~ns}$ \\
\hline
\end{tabular}

Means \pm standard error of the two production cycles. Student Newman Keuls test; $p<0.05$

whereas less differences were observed among the two types of mother plants (Table 2).

Frigo-mother plants yielded a higher amount $(70.3 \pm 33.8)$ of marketable runners per mother plants but not significantly different from the yield obtained from micro-mother plants $(61.2 \pm 27.0)$. This difference was mostly due to the higher number of runner chains produced by the frigo-mother plants $(17.5 \pm 6.5)$ in comparison with micro-mother plants $(14.1 \pm 2.5)$ (Table 2). A small difference was also observed for the higher number of discarded runners counted from micro-mother plants $(27.4 \pm 10.0)$ in comparison with frigomother plants $(21.7 \pm 10.6)$.

At the end of the two nursery cycles, runners harvested from frigo and micro-mother plants showed the same percentage of distribution among these four classes for marketable runners. For both types of mother plants, the highest percentage was classified in class $\mathrm{A}$, followed by $\mathrm{A}-$, $\mathrm{A}+$ and $\mathrm{A}++$ (Table 2). This distribution is corresponding to what generally happens in the in vivo nursery production of frigo-plants. Consequently, this is a demonstration that the use of micro-mother plants can not only yield a high number of runners as frigo-mother plants but also of the same commercial quality.

A better management of the micropropagated plants after acclimatization can further reduce the small differences observed in comparison with the frigo-mother plants, and eventually even improve their yield and quality potential. In fact, micro-mother plants have the advantage of welldeveloped root and leaf system ready to start the runner production in a short period if transplanting conditions are appropriate (Swartz et al. 1987). On the contrary, frigo-plant have to re-grow the roots and the leaf system once transplanted and generally begin to produce runners after only 1 month. Finally, it is important to highlight that during two productive cycles in the nursery, visual observations were carried out continuously without detecting any evident phenotypic variations among the two types of mother plants and their runners.

\section{Vegetative plant development in field production system}

The two types of frigo plants (from frigo and micro-mother plants) grown in open field conditions showed significant differences (ANOVA) only for some vegetative parameters (plant height, leaves number, petiole leaf length and middle leaflet height) (Table 3). These parameters were also highly influenced by the year of cultivation. While the other vegetative parameters (shoots number per plant, middle leaflet width, floral axis number and length, shoots number/plant and flowering start) had the same development for the two types of plants and independently to the year of cultivation (Table 3).

\section{Fruit yield in field production system}

The correspondence of cultivar morphology and yield capacity can be accepted as a confirmation of the efficiency of a

Table 3 Vegetative development in the field production system of plant derived from frigo and micro-mother plants, cv Alba, measured at the end of flowering period (April 2012 and 2013)

\begin{tabular}{|c|c|c|c|c|c|c|c|c|c|}
\hline $\begin{array}{l}\text { Type of } \\
\text { plant }\end{array}$ & $\begin{array}{l}\text { Shoot num- } \\
\text { ber/plant }\end{array}$ & $\begin{array}{l}\text { Leaves num- } \\
\text { ber/plant }\end{array}$ & $\begin{array}{l}\text { Petiole leaf } \\
\text { length (mm) }\end{array}$ & $\begin{array}{l}\text { Middle leaf } \\
\text { width }(\mathrm{mm})\end{array}$ & $\begin{array}{l}\text { Middle leaf } \\
\text { height }(\mathrm{mm})\end{array}$ & $\begin{array}{l}\text { Plant height } \\
(\mathrm{mm})\end{array}$ & $\begin{array}{l}\text { Floral axis } \\
\text { number }\end{array}$ & $\begin{array}{l}\text { Floral axis } \\
\text { length }(\mathrm{mm})\end{array}$ & $\begin{array}{l}\text { Flowering } \\
\text { start }\end{array}$ \\
\hline $\begin{array}{l}\text { ALBA_ } \\
\text { Frigo- } \\
\text { mother } \\
\text { plant }\end{array}$ & $3.1 \pm 0.62 \mathrm{~ns}$ & $36.8 \pm 1.5 b$ & $205 \pm 2.8 b$ & $69.8 \pm 1.0 \mathrm{~ns}$ & $87.0 \pm 1.1 \mathrm{~b}$ & $292 \pm 2.9 b$ & $11.2 \pm 0.5 \mathrm{~ns}$ & $251 \pm 6.0 \mathrm{~ns}$ & $92.2 \pm 3.4 \mathrm{~ns}$ \\
\hline $\begin{array}{l}\text { ALBA_- } \\
\text { Micro- } \\
\text { mother } \\
\text { plant }\end{array}$ & $3.2 \pm 0.64 \mathrm{~ns}$ & $44.3 \pm 1.6 \mathrm{a}$ & $224 \pm 2.8 \mathrm{a}$ & $71.4 \pm 1.0 \mathrm{~ns}$ & $94.3 \pm 1.2 \mathrm{a}$ & $318 \pm 3.3 \mathrm{a}$ & $11.7 \pm 0.4 \mathrm{~ns}$ & $248 \pm 4.7 \mathrm{~ns}$ & $92.3 \pm 3.4 \mathrm{~ns}$ \\
\hline
\end{tabular}

Means \pm standard error of the two production cycles. Student Newman Keuls test; $p<0.05$ 
strawberry plants propagation system. Frigo plants derived from frigo and micro-mother plants had the same yield capacity, in fact, at the harvest of both cultivation cycles (2012 and 2013) plants of cv. Alba originated from frigo and micro-mother plants had the same precocity index, average fruit weight (g), total weight of discarded fruit (g/plant) and total plant production (g/plant) (Table 4). No significant difference was detected for all these parameters, but Albamicro plants had a slightly higher yield of larger fruits. This trend probably can be improved by better identifying the timing of planting of this type of plants. The only differences detected from the ANOVA test was related to effect of the cultivation cycle, but only for the precocity index and total weight of discarded fruits (Table 4).

\section{Fruit quality and nutritional quality in field production system}

The concept of fruit quality is now extended to parameters used to identify the sensorial traits, including SSC ( ${ }^{\circ}$ Brix), $\mathrm{TA}(\mathrm{meqNaOH} / 100 \mathrm{~g})$, firmness $\left(\mathrm{g} / \mathrm{cm}^{2}\right)$, lightness $\left(\mathrm{L}^{*}\right)$ and Chroma $\left(\mathrm{C}^{*}\right)$, and parameters used to identify the nutritional value of the fruit, including TAC, TPH and ACY. Ripe fruit harvested at the end of the two cultivation cycles resulted with the same values of almost all these parameters (Table 5). Significant differences were detected for TPH and ACY. Fruit having frigo-mother plants as the origin had higher content of TPH $(2038 \pm 39 \mathrm{mg} \mathrm{GA} / \mathrm{kg} \mathrm{FW})$ in comparison with fruit having micro-mother plants as the origin $(1860 \pm 55 \mathrm{mg} \mathrm{GA} / \mathrm{kg} \mathrm{FW})$. On the contrary, ACY was higher in the latter fruit $(447 \pm 22 \mathrm{mg}$ Pel-3-glu/kg FW) in comparison with fruit harvested from plants originated from frigo-mother plants ( $391 \pm 27 \mathrm{mg}$ Pel-3-glu/kg FW). The only other differences were detected because of the effect of the cultivation years on the two types of plants, but only for TA, firmness, L*, TAC and ACY (Table 5). Thus confirming the stability of some traits of this cultivar with changing cultivation conditions.

\section{Discussion}

Micropropagation is usually considered of interest for production of healthy strawberry stock plants but not in other stages of commercial nursery production for the risk of phenotypic and genotypic variability (Swartz et al. 1981; Cameron et al. 1989; Jemmali et al. 1995b). Since this risk was described, specific legislations have been adopted in different countries to restrict the use of plant tissue culture only to solve phytosanitary problems. However, more recently, new results demonstrated that the variability observed can be controlled and reduced by using specific protocols for in vitro shoot proliferation (Adel El-Sawy 2007; Chang et al. 2009; Debnath 2009, 2013).

The results of our study revealed that by using a micropropagation protocol having low concentrations of BA $(0.35 \mathrm{mg} / \mathrm{l})$ and a limited number of subculture (about eight subcultures) plants propagated in vitro of $\mathrm{cv}$. Alba can be

Table 4 Fruit precocity index, average fruit weight, total weight of discarded fruit and total fruit production of frigo plants derived from frigo and micro-mother plants, cv. Alba, measured at fruit harvest of the two cultivation cycles (May 2012 and 2013)

\begin{tabular}{|c|c|c|c|c|}
\hline Type of plant & Precocity Index & Average fruit weight $(\mathrm{g})$ & $\begin{array}{l}\text { Discarded fruits }(\mathrm{g} / \\
\text { plant) }\end{array}$ & $\begin{array}{l}\text { Total pro- } \\
\text { duction }(\mathrm{g} / \\
\text { plant })\end{array}$ \\
\hline ALBA_Frigo-mother plants & $137.0 \pm 0.7 \mathrm{~ns}$ & $20.6 \pm 0.5 \mathrm{~ns}$ & $256 \pm 22 \mathrm{~ns}$ & $1017 \pm 67 \mathrm{~ns}$ \\
\hline ALBA_Micro-mother plants & $137.9 \pm 0.8 \mathrm{~ns}$ & $21.7 \pm 0.4 \mathrm{~ns}$ & $310 \pm 29 \mathrm{~ns}$ & $1091 \pm 37 \mathrm{~ns}$ \\
\hline
\end{tabular}

Means \pm standard error of the two production cycles. Student Newman Keuls test; $p<0.05$

Table 5 Sensorial and nutritional quality of fruit harvested from frigo plants derived from frigo and micro-mother plants of cv. Alba, measured at the harvest of ripe fruit of the two cultivation cycles (May 2012 and 2013)

\begin{tabular}{|c|c|c|c|c|c|c|c|c|}
\hline Type of plant & $\begin{array}{l}\text { Soluble solid } \\
\text { concentration } \\
\left({ }^{\circ} \text { Brix }\right)\end{array}$ & $\begin{array}{l}\text { Titrat- } \\
\text { able acidity } \\
(\mathrm{meqN}- \\
\mathrm{aOH} / 100 \mathrm{~g})\end{array}$ & Firmness (g) & $\begin{array}{l}\text { Lightness } \\
\left(\mathrm{L}^{*}\right)\end{array}$ & Chroma $\left(\mathrm{C}^{*}\right)$ & $\begin{array}{l}\text { Total antioxi- } \\
\text { dant capacity } \\
\text { (mmolTE/kg } \\
\text { FW) }\end{array}$ & $\begin{array}{l}\text { Total polyphe- } \\
\text { nols content } \\
\text { (mg GA/kg } \\
\text { FW) }\end{array}$ & $\begin{array}{l}\text { Total anthocy- } \\
\text { anins content } \\
\text { (mg Pel-3-glu/ } \\
\text { kg FW) }\end{array}$ \\
\hline $\begin{array}{l}\text { ALBA_Frigo- } \\
\text { mother } \\
\text { plants }\end{array}$ & $6.6 \pm 0.3 \mathrm{~ns}$ & $13.6 \pm 0.7 \mathrm{~ns}$ & $483 \pm 36 \mathrm{~ns}$ & $36.6 \pm 0.9 \mathrm{~ns}$ & $45.1 \pm 1.3 \mathrm{~ns}$ & $17.7 \pm 1.9 \mathrm{~ns}$ & $2038 \pm 39 a$ & $391 \pm 27 b$ \\
\hline $\begin{array}{l}\text { ALBA_Micro- } \\
\text { mother } \\
\text { plants }\end{array}$ & $6.6 \pm 0.3 \mathrm{~ns}$ & $13.3 \pm 0.8 \mathrm{~ns}$ & $495 \pm 32 \mathrm{~ns}$ & $36.8 \pm 1.2 \mathrm{~ns}$ & $45.5 \pm 1.6 \mathrm{~ns}$ & $17.9 \pm 1.6 \mathrm{~ns}$ & $1860 \pm 55 b$ & $447 \pm 22 a$ \\
\hline
\end{tabular}

Means \pm standard error of the two production cycles. Student Newman Keuls test; $p<0.05$ 
efficiently used as mother plants to produce new frigo plants for commercial production of high quality strawberry fruit. Indeed, frigo and micro-mother plants performed similarly when used in the nursery as mother plants. The micromother plants differed from the frigo-plants only for the lower number of shoot per plant, the number of leaf per plant and the number of runners per plant. While no differences were observed for all other parameters (Tables 1,2). This behavior was consistent for the two nursery production cycles, each one based on the use of new frigo and micromother plants. The small differences observed were not relevant for the efficiency of the nursery runners yield and commercial plant quality. Nursery production of micro-mother plants can be further improved by better identifying the timing of in vitro plant acclimatization and development before planting in the nursery. Probably, a longer development of acclimatized plants in pots before their transfer in the nursery can further increase the competitiveness of the micromother plants in comparison with the frigo-mother plants. In fact, micro-mother plants already showed a higher total production of runners but several were discarded because they were too small (Table 2). An initial more developed micro-mother plant can better support the development of these runners and consequently increase the number of high quality marketable runners (Class A) (Table 2).

Plants produced from the two cycles of nursery production, with both types of mother-plants, were then used to prepare fruit orchards for two consecutive cultivation cycles. Data collected in the two subsequent harvesting seasons, showed the same performance for all yield and sensorial quality parameters and almost all fruit nutritional parameters. Indeed, plants originating from micro-mother plants have also shown the potential to achieve higher production levels, at least for average fruit weight and total production per plant (Table 4). The high number of discarded fruits observed is common for this cultivar, known for having a high susceptibility to different pathogens when grown in open field.

Hereafter, the nursery productive and qualitative performance of micro-mother plants is comparable to the frigomother plants and with the advantage that plants from micropropagation offer a much higher phytosanitary safety of the nursery production chain combined with an easy and rapid massive propagation in response to different commercial needs.

A similar study was carried out also in Belgium testing the nursery behavior of in vivo and in vitro plants of a different cultivar Sonata (Geerts et al. 2013) in which it was confirmed the efficiency of the advanced in vitro micropropagation technology described by Geerts et al. (2009) in comparison with Dutch elite strawberry plants. In this case, comparing classical propagation versus micropropagation, it was demonstrated that the production and the quality of fruits issued from micro-mother plants are like the yield obtained from frigo-mother plants, or even with the benefit of a 10\% increase. Geerts et al. (2013), also described the possibility to use micro-mother plants for producing Elsanta strawberry runners in hydroponic propagation conditions. The combination of micro-mother plants with soil-less runner propagation techniques maintain strawberry mother plants and runners free from soil diseases, pests, mites and herbicide residues risks.

All these results are demonstrating that similar protocols can be easily transferred to other cultivars already on the market with a large commercial interest and for speeding up the large propagation of a new cultivar released from a breeding program and having an immediate interest on the market.

Unfortunately, this approach cannot be easily applied because many countries, particularly in Europe, have very strict rules for the nursery production of certified strawberry plant. For example, the Italian certification system, one of the most restrictive as other in EU, is organized in four steps, all under the control and management of different public and private institutions (Lucchi et al. 2004). In this protocol (Fig. 1a), the use of in vitro culture is restricted only to production of virus free elite plants, after thermotherapy treatment, with a limit of maximum three to four subcultures of in vitro shoot proliferation. The ex vitro, virus free, plants are then propagated in vivo for three subsequent nursery production cycles: (1) Pre-multiplication Center (a screenhouse with micro-mother plants grown in single big pallets for the first generation of in vivo runner production); (2) Pre-multiplication center 1 (plants grown on soil, only $2 \%$ of the mother plants are analytically controlled for their phytosanitary state; (3) Pre-multiplication Center 2, nursery in the field with only $0.2 \%$ of the mother plants analytically controlled for their phytosanitary state. All plants harvested from this third in vivo production cycle are used for setting up large fields for plant nursery production for the growers, thus corresponding to the fourth in vivo production cycle (the second in open field). In this last cycle are not expected any analytical control to detect potential new infections on the propagating plants due to the risk of soil and environment pest and pathogen contaminations. Allover, this plant certification protocol requires a heavy and costly organization for the management of specific structures, land and manpower needed to maintain, propagate and control the plants in the four in vivo steps, excluding the in vitro step for the preparation of elite mother plants. A minimum period of 6 years (Fig. 1) is required before the release to the market of certified plants of a new strawberry cultivar. To costs for each production cycle must be added also costs for sanitary inspections and analyses from certified public/private organization and laboratories. Last but not least important, there are costs related to soil sterilization or rotation and pest and 
disease management for each cycle so to avoid risk of new infections. This remains a main factor not easy to control in intensive strawberry nursery industry, inducing high risk of new plant infection.

The sustainability and security of this certification process is now criticized in several countries and some have already accepted to reduce to three in vivo production cycles after the in vitro step but substantially remaining a heavy and not safe nursery production method.

The results of our experiment, in line with what was proposed also by other authors (Gantait et al. 2010; Geerts et al. 2013; Debnath 2013, 2014), can be used to support the request to modify the actual legislation on strawberry nursery production, adopted by many countries, by at least adding the option to use micropropagation, with a controlled protocol, for the production of clean mother plants in the setting up of nursery fields for the production of frigo-plants directly addressed to the growers (Fig. 1b).

Cleary the application of this protocol needs the enforcement of the micropropagation capacity of the nursery, including the access to a greenhouse for acclimatization, but, on the other hand, the management costs of at least two premultiplication cycles, one of which also in the greenhouse, are eliminated. Furthermore, costs for sanitary control are highly reduced because they are only needed on plants in the conservation center, used for starting the micropropagation, and on plants sampled from the nursery. In addition, the nursery can have benefits from the increased production efficiency, the reduced request of land for managing the different pre-propagation phase, thus bringing benefits also to the environment for the reduced use of chemical inputs.

\section{Conclusions}

The results of this study confirm the possibility to use strawberry micro-mother plants to develop large nursery production of frigo-plants of high quality for the growers. This system offers the possibility to reduce costs of certification but continuing to guarantee high genetic and sanitary quality of the plants produced in the nursery. The expanding of the use of micropropagation can increase the sustainability of the strawberry nursery production system because of the increase of costs related to the need of tissue culture facilities, there is a reduction in the in vivo pre-propagation cycles, generally with high economical costs and environmental impacts, and of the phytosanitary controls. As already described by Geerts et al. (2013) the same approach can also be used for large scale production of fresh and plug strawberry plants. In this case, depending to the period of the year when plants are needed for the specific cultivation systems, the micropropagation cycle must be tuned with the timing of the in vivo production of runners and fresh plants development.

Author contributions FC and BM designed, outlined the research, interpreted the data and wrote the manuscript. FB, MM, DB and ON, performed the experiment and contributed to detect the data.

\section{Compliance with ethical standards}

Conflict of interest The authors declare that they have no conflict of interest.

Open Access This article is distributed under the terms of the Creative Commons Attribution 4.0 International License (http://creativeco mmons.org/licenses/by/4.0/), which permits unrestricted use, distribution, and reproduction in any medium, provided you give appropriate credit to the original author(s) and the source, provide a link to the Creative Commons license, and indicate if changes were made.

\section{References}

Adel El-Sawy M (2007) Somaclonal variation in micro-propagated strawberry detected at the molecular level. Int J Agric Biol 9:721-725

Anderson HM, Abbott AJ, Wiltshire S (1982) Micro-propagation of strawberry plants in vitro-effect of growth regulators on incidence of multi-apex abnormality. Sci Hortic 16(4):331-341. https ://doi.org/10.1016/0304-4238(82)90032-2

Borkowska B (2001) Morphological and physiological characteristics of micropropagated strawberry plants rooted in vitro or ex vitro. Sci Hortic 89:195-206

Boxus P (1974) The production of strawberry plants by in vitro micropropagation. J Hortic Sci 49:209-210

Boxus P (1985) Comportement du fraisier issu de micropropagation in vitro. Fruit Belge 410:106-110

Boxus P (1992) Mass production of strawberry and new alternatives for some horticultural crops. In: Kurata K, Kozai T (eds) Transplant production systems Yokohama, Japan, pp 151-162

Boxus P, Quoirin M, Laine MJ (1977) Large scale propagation of strawberry plants from tissue culture. In: Reinert J Bajaj YPS (eds.) Applied and fundamental aspects of plant cell tissue and organ culture. Springer, New York, pp 130-143

Boxus P, Jemmali A, Terzi JM, Arezki O (2000) Drift in genetic stability in micropropagation the case of strawberry. Acta Hortic 530:155-162

Cameron JS, Hancock JF, Flore JA (1989) The influence of micropropagation on yield components dry matter partitioning and gas exchange characteristics of strawberry. Sci Hortic 38:61-67

Capocasa F, Balducci F, Di Vittori L, Mazzoni L, Stewart D, Williams S, Hargreaves R, Bernardini D, Danesi L, Zhong C, Mezzetti B (2016) Romina and cristina: two new strawberry cultivars with high sensorial and nutritional values. Int J Fruit Sci 12:1-13

Chang L, Zhang Z, Han B, Li H, Dai H, He P, Tian H (2009) Isolation of DNA-methyltransferase genes from strawberry Fragaria $x$ ananassa Duch and their expression in relation to micropropagation. Plant Cell Rep 289:1373-1384

da Fonseca AP, da Silva EC, Pereira MB, de Oliveira RP, Dornelles ALC (2013) Phenotypic stability of strawberry genotypes subjected to variable number of in vitro subcultures. Cienc Rural 43 8:1345-1350

Damiano C (1980) Strawberry micropropagation. In: Proceeding of the Conference on nursery production of fruit plant through 
tissue culture applications and feasibility USDA-SEA agricultural research results ARR-NE Beltsville, pp. 11-22

Debnath SC (2009) Characteristics of strawberry plants propagated by in vitro bioreactor culture and ex vitro propagation method. Eng Life Sci 93:239-246

Debnath SC (2013) Propagation strategies and genetic fidelity in strawberries. Int J Fruit Sci 13:1-2 3-18

Debnath SC (2014) Strategies and approaches to propagate strawberry nuclear stocks using a bioreactor. Acta Hortic 1049:145-150

Debnath SC (2017) Molecular approaches for monitoring clonal fidelity and epigenetic variation in in vitro-derived strawberry plants. Acta Hortic 115:683-687. https://doi.org/10.17660/ActaHortic .2017.1156.11

Diamanti J, Capocasa F, Denoyes B, Petit A, Chartier P, Faedi W, Maltoni ML, Battino M, Mezzetti B (2012a) Standardized method for evaluation of strawberry (Fragaria x ananassa Duch) germplasm collections as a genetic resource for fruit nutritional compounds. J Food Compos Anal 28:170-178

Diamanti J, Capocasa F, Balducci F, Battino M, Hancock J, Mezzetti B (2012b) Increasing strawberry fruit sensorial and nutritional quality using wild and cultivated germplasm. PLoS ONE. https:// doi.org/10.1371/journal.pone.0046470

Gantait S, Nirmal M, Prakash KD (2010) Field performance and molecular evaluation of micropropagated strawberry. Recent Res Sci Technol 2(5):12-16

Geerts P, Terzi JM, Jemmali A, Druart P (2009) Advancement of in vitro propagation of strawberry plantlets in an industrial context. In: Mezzetti B, Ruzic D, Gajdosova A (eds) Cost action 863 - a guide to some in vitro techniques-small fruits, pp. 48-62. ISBN: 978-86-910245-3-6\$4FRI

Geerts P, Farvacque S, Bullen E, Magein H, Watillon B (2013) Micropropagation of strawberry plants in relation to field productionWallon expertise GFW-CRAW. In 2nd International Strawberry Congress-Hoogstraten Book of abstract pp. 11-12

Jemmali A, Boxus P, Kevers C, Gaspar T (1995a) Effect of the number of subcultures on anatomical and biochemical characteristics of micropropagated strawberry shoots in relation to their abnormal flowering. Med Fac Landbouww Univ Gent 60(3b):1113-1119

Jemmali A, Boxus P, Kevers C, Gasparm T (1995b) Carry-over of morphological and biochemical characteristics associated with hyperflowering of micropropagated strawberries. J Plant Physiol 147:435-440

Karhu S (2001) Growth characteristics of micropropagated strawberries. Acta Hortic 560:539-542

Keiko O, Shigeru A, Hiroshi A (2003) Effect of cytokinin on strawberry plantlets micropropagated by axillary buds. Bull Nara Prefect Agric Exp Stat 34:15-24

Larkin PJ, Scowcroft WR (1981) Somaclonal variation a novel source of variability from cell cultures for plant improvement. Theor App Genet 60:197-214
Lisiecka J (2009) Effect of type and size of strawberry mother plants on the quantity and quality of daughter plants. Acta Hortic 842:707-710

Litwinczuk W (2004) Field performance of 'Senga Sengana' strawberry plants (Fragaria x ananassa Duch) obtained by runners and in vitro through axillary and adventitious shoots. EJPAU Hortic 71:03

Lopez-Aranda JM, Pliego-Alfaro F, Lopez-Navidad I, Barsèlo-Munoz M (1994) Micropropagation of strawberry (Fragariax ananassa Duch). Effect of mineral salts benzyladenine levels and number of subcultures on the in vitro and field behavior of the obtained of the microplants and the fruiting capacity of their progeny. $\mathrm{J}$ Hortic Sci 69:625-637

Lucchi P, Benedettini G, Guermandi M, Faedi W, Turci P (2004) La nuova certificazione per una pianta di fragola di qualità. Frutticoltura 4:15-19

Mezzetti B, Giampieri F, Zhang Y-T, Zhong C-F (2018) Strawberry breeding programs and cultivation systems. J Berry Res 2018:1-17

Murashige T, Skoog R (1962) A revised medium from rapid growth and bioassays with tobacco tissue culture. Physiol Plant 15:473-497

Navatel JC, Varachaud G, Roudeillac P, Bardet A (1986) Multiplication in vitro: comportement agronimique de plants de fraisiers issus de pieds-merès produit par micropropagation par rapport au materiel Classique: Synthèse de trois annèes d'experimentation. Infos-CTIFL 21:2-8

Pertuzé R, Barrueto M, Diaz V, Gamardella M (2006) Evaluation of strawberry nursery management techniques to improve quality of plants. Acta Hortic 708:245-248. https://doi.org/10.17660/ActaH ortic. 2006.708 .40

Sansavini S, Gherardi G (1980) Selezione clonale e stabilità genetica di fragole micropropagate. Frutticoltura 5:36-49

Sansavini S, Rosati P, Gaggioli D, Toschi MF (1991) Ereditarietà e stabilità di variazioni somatiche in fragole micropropagate. Frutticoltura 9:85-91

Swartz HJ, Galletta GJ, Zimmerman RH (1981) Field performance and phenotypic stability of tissue culture-propagated strawberries. J Am Soc Hortic Sci 106:613-667

Swartz HJ, Lindstrom JT, Fiola JA (1987) The use of tissue culture propagation of strawberry in the United States CEC Biological Sciences. EUR 10871:79-100

Szczygiel A, Pierzga K, Borkowoska B (2002) Performance of micropropagated strawberry plantlets after planting in the field. Acta Hortic ISHS 567:317-320

Westphalen HJ, Billen W (1976) Erzungung von Erddbeerpflanzen in grossen Mengen durch Sprosspitzenkultur. Erwerbsobstbau 18:49-50 